\title{
WHY ARE YOUTH INTENT ON INVESTING THROUGH PEER TO PEER LENDING? EVIDENCE FROM INDONESIA
}

\author{
Ichwan $^{1}$ and Rahmatina A. Kasri ${ }^{2}$ \\ ${ }^{1}$ Universitas Indonesia, Indonesia, ichwan.ariga@gmail.com. \\ ${ }^{2}$ Universitas Indonesia, Indonesia, unirahma@gmail.com.
}

\begin{abstract}
This study aims to analyse the factors that influence the intention of youths/millennials in Jakarta, the capital of Indonesia, to invest in Peer to Peer (P2P) lending. Due to the relative newness of $\mathrm{P} 2 \mathrm{P}$ lending in Indonesia, the framework utilised is the Technology Acceptance Model (TAM), and the study involves around 400 youths, the majority of whom are Muslims. Further, the study employs Structural Equation Modelling (SEM) and logistic regression to analyse the influence of socio-demographic variables (gender, religion, marital status, education, employment, religion and income) on the intention to invest through P2P lending. The results of the study indicate that intention to invest in P2P lending is positively correlated and influenced by the attitude variable, which is itself influenced by factors including perceived ease of use, knowledge and trust in P2P lending. The results imply that the potential of youth to invest in P2P lending might be enhanced by improving technology (ease of use), literacy and trust in P2P lending. Moreover, it is suggested that those most interested in and more likely to invest through P2P lending are Muslims, have higher education and have higher incomes. With better literacy and marketing programmes, these groups could be targeted by P2P lending platforms to become potential investors. Lastly, the findings are expected to contribute to Islamic finance concepts and practices, particularly in the context of Indonesia.
\end{abstract}

Keywords: Financial Technology, Peer to Peer (P2P) lending, Technology Acceptance Model (TAM).

JEL Classification: E44; G11; G20; G23; G40.

\author{
Article history: \\ Received : September 16, 2019 \\ Revised : December 6, 2019 \\ Accepted : December 24, 2019 \\ Available online : December 27, 2019
}

https://doi.org/10.21098/jimf.v5i4.1157 


\section{INTRODUCTION}

\subsection{Background}

The rapid development of technology is becoming an opportunity and encouraging innovation in the financial sector. After the economic crisis in 2008, the financial industry underwent significant changes. There have been many 'innovations' in the financial sector throughout the world. One such innovation that has grown rapidly is the adoption of technology into financial products and services, currently known as financial technology (fintech). There are five types of fintech, namely money transfer and payment, budgeting and financial planning, saving and investment, borrowing, and insurance (Ernst and Young, 2019). Furthermore, according to Iman (2018), fintech is more than just a phenomenon. It cannot be compared to other start-ups and has the potential to fundamentally change the business and economic landscape. Indeed, these innovations enable transactions to be performed faster, more efficiently and with greater transparency.
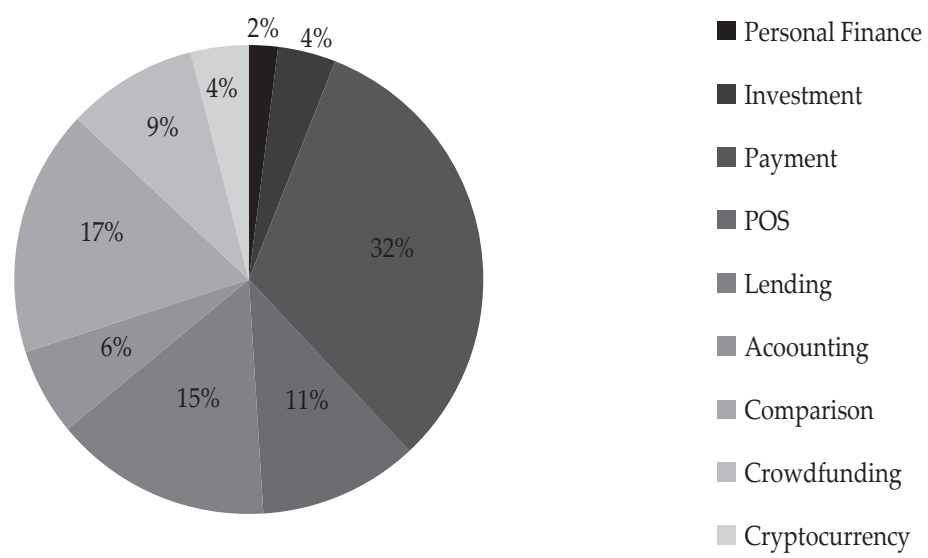

Source: Fintechnews.sg (2019)

Figure 1.

\section{Distribution of Financial Technology (Fintech) Dissemination in Indonesia}

In the context of Indonesia, financial technology is defined by the authority as the adoption of information technology in the financial system that produces new business models, products and services that have an impact on monetary and financial system stability (Bank Indonesia, 2017). In this respect, the most rapidly growing type of financial technology in the country is payment systems, with a market share of around 32 per cent. Peer to peer (P2P) lending, meanwhile, is ranked third (15 per cent) in Indonesia (see Figure 1).

As of September 2019, OJK had issued licences for 127 examples of fintech in Indonesia, including eight syariah-based fintech items. It is also notable that 122 out of the 127 fintech items, or around 96\%, are located in the Greater Jakarta area of Indonesia. Around 88 are locally owned fintech, with the remainder owned by foreign capital. In terms of investors, their number stood at 530,385, which 
was an increase of 155.06 per cent compared to the previous year. The number of borrowers also increased to 12,832,271, an increase of 194.36 per cent compared to the 2018 figure. There was also a sharp rise in the total amount of funds lent, increasing from 284.2 billion rupiahs in 2016 to 54.72 trillion rupiahs in September 2019 (OJK, 2019). Compared to other countries, in terms of the level of Islamic fintech, Indonesia was ranked third after Malaysia (21 fintech) and the UK (19 fintech) in April 2019. Additionally, there are currently more than 90 P2P lending providers in Indonesia (Damayanti, 2019).

According to PWC (2015), the rapid development of financial technology can be attributed to several factors, including the high growth of e-commerce, economic growth in developing countries where people do not fully use banking, new revenue models, a fall in banking operational costs, relatively straightforward regulations for the providers of fintech services, a large-scale business model and sophisticated technology.

Based on the data above, it can be said that the development of P2P lending in Indonesia is very promising. However, as far as we are concerned, only a small number of studies to date have attempted to analyse the factors that influence people's interest, especially that of millennials, defined here as young people born between the years 1980 of 2000, who are very close to technological advancements when it comes to investing or lending using P2P lending technology. In fact, this is a very important issue because, in the future, the financial technology sector is expected to act as a major driver of economic growth in the country.

\subsection{Objective}

Based on the background presented above, the objectives of this study are (i) to identify the factors that influence millennials in DKI Jakarta, which is the capital of Indonesia, to invest or become a lender in P2P lending, and (ii) to analyse the significant differences in the above-mentioned intention among the various millennial groups in DKI Jakarta based on their socio-demographic conditions. The results are expected to yield deeper insights regarding the potential and intention of youth to invest in P2P lending in Indonesia, which may benefit policymakers, P2P lending, other financial institutions, academics and society in general.

\section{LITERATURE REVIEW}

\subsection{Innovation, Financial Technology and Peer to Peer (P2P) Lending}

The word 'innovation' is derived from the Latin 'innovare', meaning to make a new one (Lin, 2006). In practice, innovation is a process of industrial mutation that takes place continuously to produce something new and update the economic structure. According to Schumpeter (1942, in Sledzik, 2013), innovation is closely related to entrepreneurship as one of the functions of entrepreneurial development is the encouragement of reforms in the production process by making new discoveries in both processes and new products, in order to encourage renewal in an industry. Innovation is also considered to be an important step in developing industry and increasing economic growth. 
The innovation process consists of discovery, innovation, diffusion and imitation. During the discovery and innovation stages, the impact of the innovation on the economy is still small. However, a macro effect begins during the diffusion and imitation stages of these findings. It is at this point that producers or entrepreneurs begin to understand the benefits of the new innovation, start to mass-produce it and influence the economy. According to Schumpeter (1942, in Sledzik, 2013), innovation can be in the form of:

1. New products that are higher in quality than previous products and provide more satisfaction for consumers.

2. The use of a new production method.

3. The formation of new resources as new inputs in the production process.

4. New markets for companies.

5. The emergence of new ways of managing a company.

In recent times, one of the most important innovations in finance has arguably been fintech. Fintech can be defined as the adoption of technology to improve the financial system by delivering technology-based solutions, which leads to new business models, products and services (Bank Indonesia, 2017). According to Ernst and Young (2019), there are five categories of financial technology, as summarised below.

Table 1.

List of Financial Technology Categories and Services

\begin{tabular}{|c|c|}
\hline Categories & Services \\
\hline \multirow{6}{*}{ Money Transfer and Payment } & Online Foreign Exchange \\
\hline & Overseas Remittances \\
\hline & Digital-only branchless banking \\
\hline & Peer to Peer Payments and Non-Bank Money Transfers \\
\hline & In-Store Mobile Phone Payments \\
\hline & Cryptocurrency e-Wallet \\
\hline \multirow{2}{*}{ Budgeting and Financial Planning } & Online Budgeting and Financial Planning Tools \\
\hline & Online Retirement and Pension Management Tools \\
\hline \multirow{5}{*}{ Saving and Investments } & Lending on Peer to Peer Platforms \\
\hline & Investment Via Crowdfunding Platforms \\
\hline & Online Investment Advice and Investment Management \\
\hline & Online Stock Broking \\
\hline & Online Spreadbetting \\
\hline \multirow{3}{*}{ Borrowing } & Online-only Loan Provider \\
\hline & Online Marketplace and Aggregators for loans \\
\hline & Online Loan Brokers and Broker Facilitation Websites \\
\hline \multirow{3}{*}{ Insurance } & Insurance Premium Comparison Sites \\
\hline & Insurance-Linked Smart Devices \\
\hline & App-only Insurance \\
\hline
\end{tabular}

Source: Ernst and Young (2019)

One of the most popular uses of fintech is in so-called P2P lending. P2P lending refers to the use of technology in providing financial services by bringing together 
lenders and borrowers directly (OJK, 2016). Peer-to-peer lending platforms are characterised by the ease with which lenders and borrowers can meet each other. According to Iman (2018), fintech is more than just a phenomenon. It cannot be compared to other start-ups and has the potential to fundamentally change the business and economic landscape.

Figure 2 illustrates the P2P lending business model. Typically, P2P lending involves three parties: lenders, peer-to-peer platforms and borrowers. Lenders can benefit from the interest rates set for their loan/investment, peer-to-peer platforms earn profit from the fees paid by borrowers and borrowers can profit from their business activities.

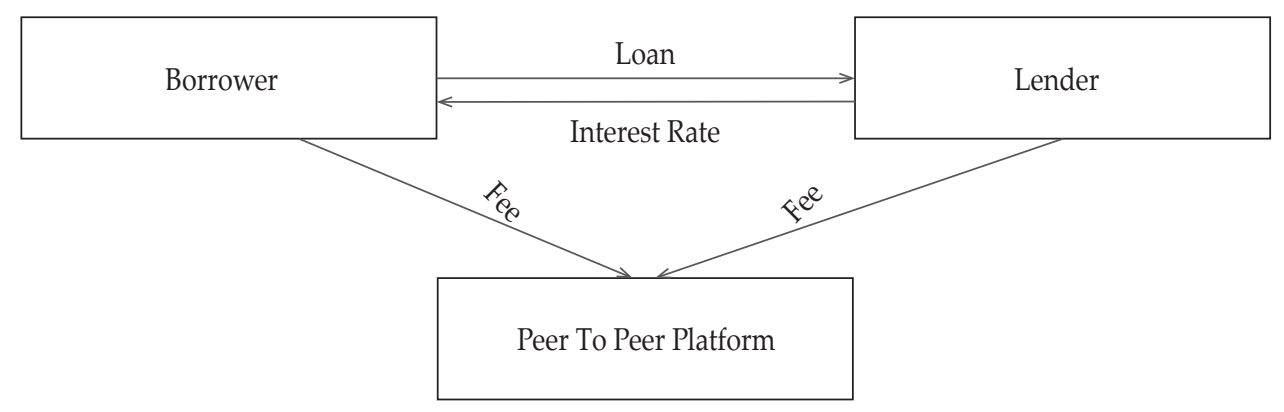

Source: Havrylchyk \& Verdier (2018)

Figure 2.

P2P lending Business Model

According to PWC (2015), the rapid development of financial technology, including P2P lending, is attributable to several factors such as the high growth of e-commerce, economic growth in developing countries where people do not fully use banking, new revenue models, the decreasing operational costs of banking, relatively simple regulations for the providers of fintech services, a large-scale business model and sophisticated technology.

\subsubsection{Technology Acceptance Model (TAM)}

In analysing the intention to adopt fintech, Davis (1985) developed the Technology Acceptance Model (TAM) from the Theory of Reasoned Action by Ajzen (1967), which aims to explain the relationship between attitudes and behaviours within human action. Thus, it is mainly used to predict how individuals will behave based on their pre-existing attitudes and behavioural intentions. In relation to this, David (1985) suggested that the use of technology can be explained or predicted through the motivation of its users, measured by several variables as follows:

1. Attitude (towards behaviour)

Attitude towards behaviour is the level of a person's evaluation towards a behaviour, in which the response can be either a positive or a negative one (Ajzen, 1991). In terms of predicting someone's intention in certain behaviours, several studies have shown how attitude indicators have a significant influence on various intentions in several types of behaviour. By learning how attitudes 
affect individual intention, it can be predicted how individuals will respond in terms of behaviours. For example, if the individual shows a good attitude or response, their intention to engage in certain behaviours will be higher, and vice versa. Thus, in this study, attitude is seen from the responses of the respondents towards investing in P2P lending.

2. Perceived Usefulness

Perceived usefulness is an individual's perception of the benefits he will receive when using technology. For example, someone will compare the benefits he obtains when investing conventionally and investing online through fintech. If he feels that investing through fintech is more useful, then his perception value regarding that action will increase. On the other hand, if he derives only a little benefit from the behaviour, the value will go down. Venkatesh and Davis (2000) explain that perceived usefulness consists of four dimensions. These are:

- The use of a system can improve job performance.

- The use of a system can increase productivity.

- The use of a system can enhance the effectiveness of performance.

- The use of a system provides benefits for individuals.

3. Perceived Ease of Use

Perceived ease of use is an individual's perception of the ease of using technology. If he feels that no great effort is required to use it, then the technology has a high perceived value of convenience, and vice versa. Furthermore, Venkatesh and Davis (2000) give the following dimensions in relation to perceptions of ease of use:

- The interaction between individuals and a system is clear and easy to understand.

- No effort is needed to be able to use the system.

- The system is easy to use.

- The system is easy to use as needed.

\subsection{Previous Studies}

A considerable number of previous studies have investigated the factors that influence the decision to invest in the financial sector, either by traditional investment or financial technology. Pikkarainen, Pikkarainen, Karjaluoto, and Pahnila (2004), for example, used the TAM approach to examine the factors that influence the acceptance levels of private banking consumers in Finland towards online banking. The study suggested that usefulness, ease of use, security and information related to the product all affect consumer acceptance of online banking. This is thought to be one of the earliest studies in the area.

More recently, many studies have investigated the subject. Chang and Chang (2013) used logistic regression methods (logit) to examine the factors that motivate people in Taiwan to use financial services online and arrived at the same conclusions as the research above. Salciuviene, Auruskeviciene, and Ivanauskiene (2014) conducted research on the key factors that influence people in Lithuania to use financial products/services online. The study used regression for its analysis and the results showed that perceived ease of use, perceived usefulness, trust, 
security and the confidentiality of data were key factors affecting Lithuanian people in using financial products/services online. This result also supports the research conducted by Pikkarainen et al. (2004). More recently, Montazemi and Qahri-Saremi (2014) conducted research into the factors that influence society to adopt online banking using structural equation modelling (SEM) methods. Their results showed that perceived ease of use and trust had a positive impact on the adoption process.

Studies on the intention to use financial services using P2P lending, however, are relatively new as P2P lending only became popular after 2010. Zhang, Tang, and Dong (2014) examined the influence of trust factors on P2P lending and concluded that trust has a positive effect on the lender's (lender / investor) decision to provide loans through P2P lending providers in China. Chen, Lou, and Van Slyke (2015) also conducted research into the factors affecting lenders' intention (lenders / investors) to lend through P2P lending in China. They used SEM and produced results which were in line with those of Zhang et al. (2014), thereby suggesting that trust is a key factor that influences lenders' intention to lend their money. The study also showed that risk factors do not affect lenders' interest in lending. This is due to the fact that lenders or investors are profit-oriented when it comes to investing, meaning that they will continue to provide a loan even when it is deemed risky if the potential exists for them to earn a large profit. Similar conclusions were suggested in the studies by Wang et al. (2015) and Chen et al. (2015).

In the context of Indonesia, relatively few studies have attempted to examine the intention to invest through P2P lending. However, Sondari and Sudarsono (2015) identified the factors that influence civil servants in Indonesia to invest in general/traditional investments. They used the theory of planned behaviour (TPB) approach and found that subjective norms and behavioural control have a significant effect on community interests to invest in Indonesia.

In addition to the perception factors that influence people's intention to invest, there can also be influence from social demographic factors such as gender, income, employment and cultural/religious factors. Bayyurt, Karisik, and Coskun (2013) examined the effects of gender on investment preferences and suggested that men tend to invest more than women. Men prefer to take risks on investments that offer appropriate returns, whereas women tend to be more risk-averse, preferring investments with enough information to mitigate risk. These results are supported by those from research by Olekar (2016), which suggested that women are more risk-averse than men.

Besides gender, income is also influential as a factor in investment intentions/ decisions. This is because the greater one's income, the greater the budget available to invest in financial services. This was one of the conclusions reached by Islamoglu, Apan, and Ayvali (2015) who conducted research in Turkey. Shafi (2014) also produced similar results showing that income and employment are one of the factors that influence an individual's interest in investing. Interestingly, Alam, Janor, Zanariah, and Ahsan (2012), who examined the effect of religiosity on the choice of financial services in Malaysia, found that a person's level of religiosity also affected his choice of financial services. These factors could be referenced by any future studies examining intention to use financial technology. 


\section{METHODOLOGY}

\subsection{Data}

This study uses a quantitative approach and the TAM to determine the factors that influence the intention or interests of the millennial generation to invest in P2P lending. The TAM is considered to be the most appropriate framework for examining intention as $\mathrm{P} 2 \mathrm{P}$ lending is a relatively new type of financial technology, whose acceptance is heavily dependent on its features. Besides, a number of previous studies have also used this framework to examine the issue (see, among others, Chen, Lou, \& Van Slyke, 2015; Pikkarainen, Pikkarainen, Karjaluoto, \& Pahnila, 2004; Zhang, Tang, \& Dong, 2014).

Primary data are used in this research, collected from a survey targeted at millennials, or those born between the years of 1980 and 2000 (KBBI, 2019). This research focuses on millennials as they account for the majority of internet users in Indonesia (APJII, 2017). It is well understood that millennials are closer to technology than other age groups. As such, since financial technology services are based on technology, millennials should have a greater understanding of fintech and also use it more, including P2P lending services. The survey was conducted in an online format in December 2018. Social media was used to reach the respondents, who are youths/millennials aged 18-35 years living in DKI Jakarta province and who have never used P2P lending before. In this respect, purposive sampling was used and was regarded as the most appropriate sampling method, as only respondents who met the above-mentioned criteria could participate in the survey.

Furthermore, it is suggested that the sample size must be at least five times the number of question indicators to be analysed (Hair, Black, Babin, \& Anderson, 2014). Therefore, this study should have a minimum of 130 respondents (i.e. 26 question items multiplied by five). However, it actually recruited as many as 400 respondents, which can be expected to generate more accurate findings and analyses for the research.

\subsection{Model Development}

Previous studies have shown that, under the TAM framework, there are several factors that might influence the intention to invest in P2P lending (see, among others, Chen et al., 2015; Pikkarainen et al., 2004; Zhang et al., 2014). Therefore, based on the research framework used, the hypotheses developed in this study are illustrated in the following figure. 


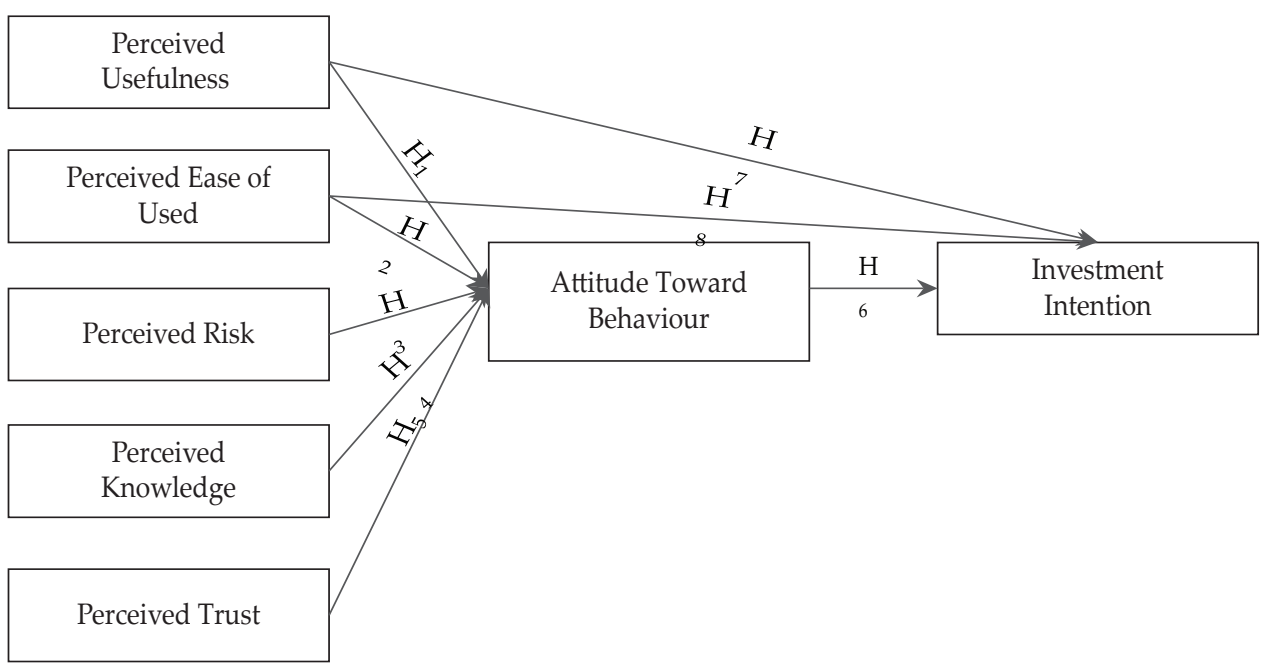

Figure 3. Model Development and Research Hypotheses

More specifically, the hypotheses tested in this study are as follows:

1. H1: Millennials' perceptions of the benefits of P2P lending have a positive and significant effect on attitudes to invest in P2P lending.

2. H2: Millennials' perceptions of the ease of use of P2P lending have a positive and significant effect on attitudes to invest in P2P lending.

3. H3: Millennials' perceptions of the risk of P2P lending have a positive and significant effect on attitudes to invest in P2P lending.

4. H4: Millennials' perceived knowledge of P2P lending has a positive and significant effect on attitudes to invest in P2P lending.

5. H5: Millennials' perceived trust in P2P lending has a positive and significant effect on attitudes to invest in P2P lending.

6. H6: Millennials' attitudes towards P2P lending have a positive and significant effect on investment intention.

7. H7: Millennials' perceptions of the benefits of P2P lending have a positive and significant effect on investment intention.

8. H8: Millennials' perceived ease of use of P2P lending has a positive and significant effect on investment intention.

\subsection{Method}

To answer the research questions and achieve the research objectives, the study constructed a questionnaire and collected the relevant primary data. The questionnaire was divided into the following sections: screening questions, demographic data, general questions, main questions and closed questions. The main questions were closed-ended questions with the responses given on a fivepoint Likert scale ( $1=$ strongly disagree $-5=$ strongly agree). 
Following Chandio et al. (2017) and Wang (2015), the dependent variable used in this study is investment intention while the independent variables are perceived usefulness, perceived ease of use, knowledge, perceived trust, attitude towards investment and. As such, the empirical model in this study is as follows:

$$
\begin{aligned}
& \mathrm{AB}=\gamma 11^{*} \mathrm{PU}+\mathrm{\gamma} 12^{*} \mathrm{PEOU}+\mathrm{\gamma} 13^{*} \mathrm{PR}+\mathrm{\gamma} 14^{*} \mathrm{PK}+\mathrm{\gamma} 15^{*} \mathrm{PT}+C_{1} \\
& \mathrm{II}=\beta 1^{*} \mathrm{AB}+\gamma 21^{*} \mathrm{PU}+\gamma 22^{*} \mathrm{PEOU}+C_{1}
\end{aligned}
$$

In which:

$\begin{array}{ll}\text { AB } & \text { : Attitude Behaviour } \\ \text { PU } & \text { : Perceived Usefulness } \\ \text { PEUO } & \text { : Perceived Ease of Use } \\ \text { PK } & \text { : Perceived Knowledge } \\ \text { PT } & \text { : Perceived Trust } \\ \text { II } & \text { : Investment Intention } \\ \text { C } & \text { : Error }\end{array}$

The analysis using SEM comprised several stages. First to be conducted were validity and reliability tests, the aim of which was to measure the level of validity of the questionnaire and its ability to answer the research questions. The values obtained from the validity and reliability tests must be above 0.5 (Valk \& Miller, 1992). This is followed by a goodness of fit test which aims to determine the suitability of the model. Finally, hypotheses testing is performed to answer the research questions and achieve the research objectives.

Meanwhile, in order to analyse the differences in intention to invest in P2P lending among millennial groups in Jakarta with various socio-demographic background factors (gender, religion, marital status, education level, employment and income), the study constructed a logistic regression model and performed inferential statistics as used in Malmarugan (2008), who looked at customers' intention to purchase apparel online in Chennai, India. The formula is as follows:

$$
M I^{*}=\beta_{0}+\beta_{1} \text { Gender }+\beta_{2} \text { Marry }+\beta_{3} \text { Religion }+\beta_{4} E d u+\beta_{5} \text { Work }+\beta_{6} \text { Inc }+e
$$

In which:

$\begin{array}{ll}\text { MI } & \text { : Investment Intention } \\ \beta_{0} & \text { : Intercept Parameter } \\ \mathrm{B} & \text { : Coefficient Parameter } \\ \text { Marry } & : \text { Marital Status } \\ \text { Religion } & : \text { Religion } \\ \text { Edu } & : \text { Education } \\ \text { Work } & : \text { Work } \\ \text { Inc } & : \text { Income } \\ \mathrm{E} & : \text { Standard Error }\end{array}$




\section{RESULTS AND ANALYSIS}

\subsection{Results}

This section presents the findings and analysis in order to identify the determinants of the millennials' intention to invest in P2P lending and the characteristics of such millennials. It also contains the respondents' general profile, model testing, hypothesis testing, structural model testing and socio-demographic testing.

\subsubsection{Respondent Profile}

In general, the findings of the study suggest a relatively balanced gender composition amongst the respondents (i.e. $53 \%$ are males and $47 \%$ are females). In addition, most of the respondents are aged under 25 years ( $66 \%$ of the respondents), the majority are Muslims (90\%) and are educated to undergraduate degree level. These are also the characteristics of typical millennials in Jakarta.

\subsubsection{Model Testing}

The following table displays the results of the validity and reliability tests. The results show that all the loading factor values are above 0.5 , thus indicating that all of the questions are valid to explain the variable (Valk \& Miller, 1992). In addition, the Cronbach's alpha value of all variables is above 0.6 , meaning that all of the variables are considered reliable and can be used for further analysis in the research (Malhotra, 2007).

Table 2.

Results of the Validity and Reliability Tests

\begin{tabular}{lcc}
\hline Variable & Cronbach's Alpha & Composite Reliability \\
\hline Perceived Usefulness & 0.96 & 0.86 \\
\hline Perceived Ease of Use & 0.97 & 0.92 \\
\hline Perceived Risk & 0.96 & 0.89 \\
\hline Perceived Knowledge & 0.98 & 0.96 \\
\hline Perceived Trust & 0.93 & 0.84 \\
\hline Attitude & 0.98 & 0.92 \\
\hline Intention & 0.99 & 0.96 \\
\hline
\end{tabular}

Table 2 shows the results of the Goodness of Fit test or the model feasibility test. The results show that the values of NFI, NNFI and CFI are all above 0.90, meaning that the model used in this study is already good (i.e. good fit). Based on the following four values, it can be concluded that the model used in this study is good enough or feasible to use. 
Table 3.

Results of the Goodness of Fit Test

\begin{tabular}{lc}
\hline & Value \\
\hline Normed Fit Index (NFI) & 0.914 \\
Non-Normed Fit Index (NNFI) & 0.919 \\
Comparative Fit Index (CFI) & 0.930 \\
Goodness of Fit Index (GFI) & 0.805 \\
\hline
\end{tabular}

Next, structural testing was performed and produced the following results:

Table 4.

Structural Testing

\begin{tabular}{lccc}
\hline Variable & Coef & T-Value & P-Value \\
\hline Attitude Behaviour & 0.856 & 11.527 & $0.00^{\text {*** }}$ \\
Perceived Usefulness & 0.549 & 6.106 & $0.00^{\text {*** }}$ \\
Perceived Ease of Use & -0.383 & -6.233 & $0.00^{\text {*** }}$ \\
Error Var & 0.114 & & \\
R-Square & 0.885 & & \\
\hline
\end{tabular}

Source: Lisrel's Output

The value of the regression coefficient shows that the intention variable is influenced by the attitude, perceived usefulness and perceived ease of use variables. The respondents' intention to invest was most influenced by the attitude variable, as shown by the highest $t$-value of 11.53. Specifically, the attitude towards behaviour variable is important in determining the intention, as the respondents' positive or negative attitude towards a perception will determine their intention (Ajzen, 1991). In the equation above, it can also be seen that the value of $R^{2}$ (coefficient of determination) is $88.5 \%$, which implies that around $88.5 \%$ of the variation in the intention variable can be explained by the variables of attitude, perceived usefulness and ease of use.

\subsection{Analysis}

Following the stages explained above and to ensure that the best model is obtained, the SEM method produces the following results: 
Table 5.

Hypothesis Testing

\begin{tabular}{|c|c|c|c|c|c|}
\hline Hypothesis & & Coef. & T-Value & P-Value & Conclusion \\
\hline Hypothesis 1 & $\begin{array}{c}\text { Perceived Usefulness-> } \\
\text { Attitude }\end{array}$ & -0.247 & -1.51 & 0.131 & Rejected \\
\hline Hypothesis 2 & $\begin{array}{c}\text { Perceived Ease of Use -> } \\
\text { Attitude }\end{array}$ & $0.206^{* *}$ & 3.12 & $0.002^{* *}$ & Accepted \\
\hline Hypothesis 3 & $\begin{array}{l}\text { Perceived Risk-> } \\
\text { Attitude }\end{array}$ & 0.0594 & 1.5 & 0.134 & Accepted \\
\hline Hypothesis 4 & $\begin{array}{c}\text { Perceived Knowledge -> } \\
\text { Attitude }\end{array}$ & $-0.151^{* *}$ & -3.08 & $0.002^{* *}$ & Rejected \\
\hline Hypothesis 5 & $\begin{array}{l}\text { Perceived Trust-> } \\
\text { Attitude }\end{array}$ & $1.198^{* * *}$ & 6.96 & $0.000^{* * *}$ & Accepted \\
\hline Hypothesis 6 & Attitude $->$ Intention & $0.75^{* * *}$ & 11.51 & $0.000^{* * *}$ & Accepted \\
\hline Hypothesis 7 & $\begin{array}{l}\text { Perceived Usefulness -> } \\
\text { Intention }\end{array}$ & $0.523^{* * *}$ & 6.57 & $0.000^{* * *}$ & Accepted \\
\hline Hypothesis 8 & $\begin{array}{l}\text { Perceived Ease of Use -> } \\
\text { Intention } \\
\end{array}$ & $-0.367^{* * *}$ & -6.22 & $0.000^{* * *}$ & Rejected \\
\hline
\end{tabular}

$* * *, * *$ and $*$ denote the significance levels of $1 \%, 5 \%$ and $10 \%$ respectively.

Hypothesis 1 is rejected because the result of the hypothesis testing gives a $\mathrm{t}$-value of -1.51 , which means there is a negative and insignificant relationship between the respondents' perceptions of the usefulness of P2P lending and the respondents' attitude. The t-value obtained does not match the standard value of $-1.96 \geq$ T-value $\geq 1.96$. Based on the question items in the questionnaire, approximately 35 per cent of the respondents do not perceive that investing in P2P lending provides more benefits. This perception presumably arises due to a lack of understanding on the part of the respondents of the P2P lending concept and business model, meaning it is difficult to define the benefits of investing in P2P lending. The findings of this study are in line with the conclusions of Yang, Liu, and Zhou (2011) and Venkatesh and Davis (1996) in Chuttur (2009), who state that the perception of benefits has a more direct influence on intention than the intermediary effect of attitude and research variables. Meanwhile, Bashir and Madhavaiah (2014), who conducted research in India, show that the perception of benefits has a negative impact and does not significantly affect an individual's intention to invest in the financial sector.

Hypothesis 2 is accepted because the result of the hypothesis testing is a $\mathrm{t}$-value of 3.12. This result is in accordance with the standard value used of -1.96 $\geq \mathrm{T}$-value $\geq 1.96$, which means there is a positive and significant relationship between the respondents' perceptions of the ease of using P2P lending and their attitude towards P2P lending. This is because all of the respondents are millennials who are accustomed to accessing the internet. The easier and more attractive they perceive a website/platform to be, the more often they will use it. Pikkarainen et al. (2004), Montazemi, and Qahri-Saremi (2014) and AlKailani (2016) all conducted similar studies and stated that the desire to adopt online financial services is positively and significantly influenced by the convenience variable. Thus, their studies support the results of this study. 
Hypothesis 3 is accepted because the results of the hypothesis testing indicate a positive relationship between the risk perceptions of the respondents' attitudes in $\mathrm{P} 2 \mathrm{P}$ lending. This is despite the fact that the relationship is not significant because the resulting $\mathrm{t}$-value of 1.5 is not in accordance with the recommended provision of $-1.96 \geq \mathrm{T}$-value $\geq 1.96$. This finding can partly be explained by the fact that the majority of the respondents in this study do not yet have sufficient knowledge related to P2P lending. This result is in line with the findings of Chen et al. (2015), who demonstrated a positive influence between risk and the desire of respondents to provide loans/invest in P2P lending.

Hypothesis 4 is rejected because, based on the hypothesis testing, it produces a $t$-value of -3.08 . This result is in accordance with the standard value of $-1.96 \geq$ $\mathrm{T}$-value $\geq 1.96$, meaning there is a negative and significant relationship between the respondents' knowledge and their attitude to investing in P2P lending. This finding is in contrast to that found by Pikkarainen et al. (2004), yet it can be explained on the basis that the millennial generation know that the current financial technology regulation in Indonesia is unclear and not optimal, thereby discouraging their intention to invest.

Hypothesis 5 is accepted because the results of the hypothesis testing show a positive and significant relationship between the respondents' perceptions of trust in P2P lending and their attitudes towards it (i.e. the $t$-value is 6.96, well above the critical value of $-1.96 \geq \mathrm{T}$-value $\geq 1.96$ ). The trust variable is very important because it relates to security risk, the truth of information and confidentiality. Indeed, Wang et al. (2015) suggested that there are three factors that influence trust in $\mathrm{P} 2 \mathrm{P}$ lending, namely the organiser's reputation, their integrity in providing and information and perceptions of asymmetric information. Salciuviene et al. (2014), Chen et al. (2015) and Zhang et al. (2014) conducted similar studies and stated that the key factor determining an individual's attitude to online financial services is trust. Thus, the results of this study are in line with those of the above-mentioned studies. If an individual has a greater level of trust in a platform, meaning they know about the risk and benefit of the investment, we can conclude that this perceived trust improves their willingness to invest in P2P lending.

Hypothesis 6 is accepted, as the hypothesis testing shows a positive and significant relationship between the variables of respondents' attitudes to P2P lending and their interest to invest in it. The resulting t-value is 11.51, well above the critical $t$-value range of $-1.96 \geq \mathrm{T}$-value $\geq 1.96$. Attitudes and interest have a very close relationship because the attitude variable shows the respondents' evaluation of a certain behaviour with the support of several variables such as ease of use, information and others because the supporting variables have a positive impact on the respondents' intention to invest in P2P lending. This finding is consistent with those of Banan (2010), Riffai, Grant, and Edgar (2011) and AlKailani (2016).

Hypothesis 7 is accepted, as the hypothesis testing suggests a positive and significant relationship between the respondents' perceptions of the benefits to be gained through $\mathrm{P} 2 \mathrm{P}$ lending and their intention to invest in it (i.e. the resulting $\mathrm{t}$-value is 6.57 , well above the critical $\mathrm{t}$-value of $-1.96 \geq \mathrm{T}$-value $\geq 1.96$ ). This is in accordance with the current conditions where someone will be very interested in using or doing new things that provide additional benefits to them; for example, a 
strong interest in e-commerce, where someone gains benefits such as a convenient way to shop. Chandio et al. (2017) and Sondari and Sudarsono (2015) support these findings in their studies, identifying that investment interest is influenced positively and significantly by benefit variables.

Lastly, hypothesis 8 is rejected as the results of the hypothesis testing produce a t-value of -6.22, meaning that the perception of the respondents' ease of using $\mathrm{P} 2 \mathrm{P}$ lending has a negative and significant effect on investment intention. This is because most of the respondents did not know about it and none of them had ever used it. This led to anxiety and doubt on the part of the respondents as to whether $\mathrm{P} 2 \mathrm{P}$ lending is easy to use, thus negatively impacting their interest to invest. This finding is in line with those of $\mathrm{Lu}$ and Su (2009) and Islam, Kim Cheng Low, and Hasan (2013), who suggested that the presence of a large degree of anxiety among first-time investors will have a negative impact on their intention to invest in such a new fintech.

\subsection{Socio-Demographic Analysis}

In analysing the effect of the socio-demographic variables on millennials' investment intention, the logistic regression produces the following results: 
Table 5.

Logistic Regression Output

\begin{tabular}{|c|c|}
\hline Number of Obs & $=400$ \\
\hline LR chi2(10) & $=36.15$ \\
\hline Prob $>$ chi 2 & $=0.00001$ \\
\hline Pseudo R2 & $=0.1058$ \\
\hline Log likelihood & $=-152.73378$ \\
\hline
\end{tabular}

\begin{tabular}{|c|c|c|c|c|c|c|c|}
\hline Variable & Coef. & $\begin{array}{l}\text { Odd } \\
\text { ratio }\end{array}$ & std. error & $\mathrm{Z}$ & $P>|z|$ & \multicolumn{2}{|c|}{$\begin{array}{l}\text { [95\% Conf. } \\
\text { Interval] }\end{array}$} \\
\hline Gender & -0.228 & 0.796 & 0.305 & -0.75 & 0.454 & -0.827 & 0.369 \\
\hline Marital status & -0.392 & 0.675 & 0.459 & -0.86 & 0.392 & -1.291 & 0.507 \\
\hline Religion & $0.986^{* *}$ & $2.681^{* *}$ & 0.440 & 2.24 & 0.025 & 0.123 & 1.849 \\
\hline \multicolumn{8}{|l|}{$\begin{array}{l}\text { Edu (Base: Junior-Senior } \\
\text { High School) }\end{array}$} \\
\hline Undergrad & $0.660^{*}$ & $1.934^{*}$ & 0.393 & 1.68 & 0.093 & -0.110 & 1.430 \\
\hline Postgrad & $2.087^{*}$ & $8.062^{*}$ & 1.148 & 1.82 & 0.069 & -0.163 & 4.338 \\
\hline \multicolumn{8}{|l|}{$\begin{array}{l}\text { Occupation (Base: } \\
\text { Unemployment) }\end{array}$} \\
\hline Government sector & $-1.219^{* *}$ & $0.295^{* *}$ & 0.503 & -2.43 & 0.015 & -2.204 & -0.234 \\
\hline Private sector & 0.626 & 1.870 & 0.656 & 0.95 & 0.34 & -0.661 & 1.912 \\
\hline Others & $-1.680^{* *}$ & $0.186^{* *}$ & 0.704 & -2.39 & 0.017 & -3.060 & 0.230 \\
\hline \multicolumn{8}{|l|}{$\begin{array}{l}\text { Income (Base: } \\
<\mathrm{Rp} 3,600,000)\end{array}$} \\
\hline Rp3,600,000-Rp7,000,000 & $1.032^{* *}$ & $2.808^{* *}$ & 0.456 & 2.27 & 0.023 & 0.139 & 1.926 \\
\hline$>\operatorname{Rp7} 7,000,000$ & $1.178^{* *}$ & $3.249^{* *}$ & 0.562 & 2.1 & 0.036 & 0.076 & 2.280 \\
\hline Cons & 0.448 & 1.565 & 0.470 & 0.95 & 0.341 & -0.473 & 1.369 \\
\hline
\end{tabular}

***, ** and * denote the significance levels of $1 \%, 5 \%$ and $10 \%$ respectively.

From the results above, it can be seen that several variables influence investment intention, namely religion, education, occupation and level of income. These results, with the exception of the religious factor, are quite intuitive as the variables are indeed some of the important and explicit determinants of investment behaviours. Nevertheless, the gender and marital status variables are not found to affect intention to invest through P2P lending. These results imply that there is no significant difference in the preference to invest in P2P amongst different gender and marital statuses. This is presumably influenced by the fact that financial technology is not directly related to gender and/or marital status. Indeed, Bhavani and Shetty (2017), in their study, found that gender did not affect investment intention.

Interestingly, the study found that the religious variable has a significant effect on the millennials' investment intentions. Indeed, the Muslim respondents were found to be more interested in investing in P2P lending than the nonMuslim respondents. This is probably related to the feature of P2P lending by which investors/lenders and borrowers are directly connected, which could be 
seen as providing more fairness/justice and transparency in the transaction. It is well known in Islamic economic literature that justice is indeed a basic value in Islamic economics (Kasri, 2016). This result is in line with the finding of Alam et al. (2012) who conducted a similar study in Malaysia and suggested that religion has an important influence on the choice of financial services. On the other hand, according to Jamaludin (2013), in Malaysia, there is no significant difference in investment decisions between Muslims and non-Muslims because investors choose an investment platform based on their level of trust in it and not based on their religion. This reflects Malaysia's balanced proportion of Muslims and non-Muslims. An important factor for Muslims is knowing that the product they choose complies with the rules of their faith.

Furthermore, the study identified a positive influence of education and income level on the intention to use P2P lending. Indeed, those with a higher level of education and higher incomes tended to also have a higher probability of investing in fintech. These results are very intuitive. Higher education will support an individual's ability to access or use information technology and help them attain a better understanding of the use of P2P lending. Widayat (2010) conducted a similar study and stated that level of education influences one's interest in investing. A higher income also enables more investment, including in P2P lending, as suggested by previous studies such as that by Islamoglu, Apan and Ayvali (2015) in Turkey. Finally, related to occupation, the study suggests that being a government employee and working in other/informal sectors serves to reduce the likelihood of investing in P2P lending. This is probably related to the relatively income offered by these job sectors. Nevertheless, more studies are needed to elaborate the findings.

\section{CONCLUSION AND RECOMMENDATION}

\subsection{Conclusion}

This study aimed to analyse the factors that influence the intention of youth in Jakarta, the capital of Indonesia, to invest in P2P lending. As P2P lending is relatively new in Indonesia, the framework utilised was the TAM approach involving around 400 youths, the majority of whom were Muslims. Further, the study employed SEM and logistic regression to analyse the influence of sociodemographic variables (gender, religion, marital status, education, employment, religion and income) on the intention to invest through P2P lending.

Based on the findings and analyses, the study presents at least two conclusions. First, the millennials' intention to invest in P2P lending is both positively correlated with and strongly influenced by the attitudes variable. While attitudes themselves are influenced by the perceived ease of use, perceived knowledge and perceived trust variables. These results imply that youths' intention to invest in $\mathrm{P} 2 \mathrm{P}$ lending is strongly influenced by their knowledge regarding various aspects of $\mathrm{P} 2 \mathrm{P}$ lending (including mechanism, risk and return), their view of the ease of use of the platform and their trust in the $\mathrm{P} 2 \mathrm{P}$ provider. This is in line with the perspective suggesting that an economic agent will prefer technology that is easy to understand and use and that it is chosen by people or groups who already have the credibility to minimise the risk of fraud. 
It is also notable that, of the three variables, the one that exerted the greatest influence on the respondents' attitudes was the perception of trust. This is very intuitive considering that almost all, if not all, transactions are carried out electronically through a P2P lending platform. Trust in the credibility of the system and provider are thus critical for transactions to take place; indeed, without them, the business could not survive. Therefore, it is very important for a P2P lending provider to maintain this trust factor.

Second, differences in the intention to invest in P2P lending are found between millennials from different socio-demographic backgrounds. Greater P2P lending investment intention is found in groups with Islamic religiosity, higher education and higher income. These factors imply that such groups contain the most potential investors for P2P lending in the future. In Indonesia, as the world's largest Muslim country, this presents an opportunity for P2P lending platforms to grow their businesses more than those in other countries.

\subsection{Recommendation}

Based on the results of the study, two recommendations are proposed. First, it is important to improve public education related to P2P lending among millennials, including Muslims and those with higher education and higher incomes. As this study has identified, this can be done by highlighting the ease of use (including the ease of using P2P lending applications) and trust (including security) in investing in P2P lending. This should be carried out by both regulators and P2P lending platforms themselves. Second, according to POJK No.77/2016, OJK, as the regulator, must play an active role in improving society's financial literacy and ensure that P2P lending platforms are registered with the relevant authority to minimise the risk of fraud that is detrimental to the community. Therefore, it must intensify its literacy programmes in order to increase society's knowledge and minimise the risk of fraud that may occur when members of the community invest in P2P lending. Finally, as this research has focused only on millennials in Jakarta who have never used P2P lending before, future research could extend the scope of the study to other parts of Indonesia. It could also improve the models and conduct comparison studies between various groups of communities in the country. These would ultimately be expected to enrich the Islamic economics literature, particularly in relation to Islamic P2P lending.

\section{REFERENCES}

Alam, S. S., Janor, H., Zanariah, C. A. C. W., \& Ahsan, M. N. (2012). Is Religiosity an Important Factor in Influencing the Intention to Undertake Islamic Home Financing in Klang Valley. World Applied Sciences Journal, 19(7), 1030-1041.

AlKailani, M. (2016). Factors Affecting the Adoption of Internet Banking in Jordan: An extended TAM model. Journal of Marketing Development $\mathcal{E}$ Competitiveness, 10(1).

APJII (2017). Infografis Penetrasi dan Perilaku Pengguna Internet Indonesia 2017. APJII. 
Badan Pusat Statistik Indonesia (2018). Produk Domestik Regional Bruto ProvinsiProvinsi di Indonesia Menurut Lapangan Usaha. Jakarta: Badan Pusat Statistik.

Banan, M. R. (2010). E-banking and Managerial Challenges. Computer Science $\mathcal{E}$ Telecommunications, 24(1).

Bank Indonesia (2015). Laporan Perekonomian Indonesia 2014. Jakarta: Bank Indonesia.

Bank Indonesia (2017). Peraturan Bank Indonesia Nomor 19/12/PBI.2017. Tentang Penyelenggaraan Teknologi Finansial.

Bashir, I., \& Madhavaiah, C. (2015). Consumer Attitude and Behavioural Intention towards Internet Banking Adoption in India. Journal of Indian Business Research, 7(1), 67-102.

Bayyurt, N., Karışık, V., \& Coşkun, A. (2013). Gender Differences in Investment Preferences. European Journal of Economic \& Political Studies, 6(1).

Bhavani, G., \& Shetty, K. (2017). Impact of Demographics and Perceptions of Investor on Investment Avenues. Accounting and Finance Research, 6(2).

Chang, C. C., \& Chang, P. C. (2013). A Study on Taiwan Consumers' Adoption of Online Financial Services. Asia Pacific Management Review, 197-219.

Chen, D., Lou, H., \& Van Slyke, C. (2015). Toward an Understanding of Online Lending Intentions: Evidence from a Survey in China. CAIS, 36, 17.

Chuttur, M. (2009). Overview of Technology Acceptance Model: Origins, Developments, and Future Direction. Working Paper on Information Systems.

Damayanti, D. (2019). Prospek Pengembangan Ekonomi dan keuangan Syariah Nasional. Makalah disampaikan pada Sharia Talk ILUNI FEB UI, 8 Agustus 2019.

Ernst and Young (2019). Global FinTech Adoption Index 2019. Ernst and Young.

Hair, J. F., Black, W. C., Babin, B. J., \& Anderson, R. E. (2014). Multivariate Data Analysis. Exploratory Data Analysis in Business and Economics (Seventh edition). Edinburgh: Pearson Education Limited.

Havrylchyk, O., \& Verdier, M. (2018). The Financial Intermediation Role of the P2P Lending Platforms. Comparative Economic Study, 115-130.

Hooper, D., Coughlan, J., \& Mullen, M. (2008). Structural Equation Modelling: Guidelines for Determining Model Fit. The Electronic Journal of Business Research Methods, 6(1), 53-60.

Iman, N. (2018). Assessing the Dynamics of Fintech in Indonesia. Investment Management and Financial Innovations, 15(4), 296-303.

Islam, Z., Kim Cheng Low, P., \& Hasan, I. (2013). Intention to Use Advanced Mobile Phone Services (AMPS). Management Decision, 51(4), 824-838.

Islamoğlu, M., Apan, M., \& Ayvalı, A. (2015). Determination of Factors Affecting Individual Investor Behaviours: A Study on Bankers. International Journal of Economics and Financial Issues, 5(2), 531-543.

Jamaludin, N. (2013). Religion and Individual Investment Choice Decision: The Case of Malaysia. International Journal of Business and Social Science, 4(1).

Kasri, R. A. (2016). Effectiveness of Zakah Targeting in Alleviating Poverty in Indonesia. Al-Iqtishad: Journal of Islamic Economics, 8(2), 169-186.

Katadata.co.id. (2017). https://databoks.katadata.co.id/datapublish/2017/10/11/ penetrasi-Layanan-perbankan-indonesia-tertinggal-darimalaysia

Katadata.co.id. (2018). https://databoks.katadata.co.id/datapublish/2018/02/23/ usia-produktif-mendominasi-pengguna-internet. 
Katadata.co.id. (2018). https://katadata.co.id/infografik/2018/03/08/skemapinjaman-melalui-fintech-semakin-diminati.

Kontan.co.id. (2018). http://keuangan.kontan.co.id/news/tekfin-peer-to-peerlending-telah-menyalurkan-pembiayaan-rp -25-triliun-tahun-lalu.

Lin, C. (2006). A Study on the Organizational Innovations in Taiwan's Logistics Industry. The Business Review, Cambridge, 5(1), 270.

Lu, H.-P., \& Su, P. (2009). Factors Affecting Purchase Intention on Mobile Shopping Websites. Internet Research, 19(4), 442-458.

Malmarugan, D. (2008). Strategic Model for Predicting Customer's Intention to Purchase Apparel Online. Innovative Marketing, 4(1).

Montazemi, A. R., \& Qahri-Saremi, H. (2015). Factors Affecting Adoption of Online Banking: A Meta-Analytic Structural Equation Modeling Study. Information \& Management, 52(2), 210-226.

Napitupulu, S. K., Rubini, A. F., Khasanah, K., \& Rachmawati, A. D. (2017). Perlindungan Konsumen pada Fintech. Jakarta: Departemen Perlindungan Konsumen.

OJK (2019). Perkembangan Fintek Lending Periode Agustus 2019. https://www. ojk.go.id/id/kanal/iknb/data-dan-statistik/fintech/Pages/Statistik-FintechLending-Periode-Agustus-2019.aspx.

OJK.go.id. (2018). https://sikapiuangmu.ojk.go.id/FrontEnd/CMS/Category/63

Olekar, R. O., \& M, V. (2016). Gender Difference in Investment Behavior - A Case Study. Acme Intellects International Journal of Research in Management, Social Sciences \& Technology.

Otoritas Jasa Keuangan (2016). POJK No. 77 Tahun 2016. Tentang Layanan Pinjam Meminjam Uang Berbasis Teknologi.

Pikkarainen, T., Pikkarainen, K., Karjaluoto, H., \& Pahnila, S. (2004). Consumer Acceptance of Online Banking: An Extension of the Technology Acceptance Model. Internet Research, 14(3), 224-235.

PWC (2015). States of Guernsey. PWC.

Republik Indonesia (2003). Undang-Undang Republik Indonesia Nomor 20 Tahun 2003. Tentang Sistem Pendidikan Nasional.

Riffai, M. M. M. A., Grant, K., \& Edgar, D. (2012). Big TAM in Oman: Exploring the Promise of Online Banking, its Adoption by Customers and the Challenges of Banking in Oman. International Journal of Information Management, 32(3), 239250.

Salciuviene, L., Auruskeviciene, V., \& Ivanauskiene, N. (2014). Key Drivers Affecting Customer Intention to Purchase Financial Services Online. Engineering Economics, 25(2), 194-202.

Shafi, M. (2014). Determinants Influencing Individual Investor Behavior in Stock Market: A Cross Country Research Survey. Nigerian Chapter of Arabian Journal of Business and Management Review, 62(1100), 1-12.

Śledzik, K. (2013). Schumpeter's view on Innovation and Entrepreneurship. S. Hittmar (Ed.), Management Trends in Theory and Practice. Faculty of Management Science and Informatics, University of Zilina \& Institute of Management by University of Zilina. 
Sudarsono, M. C. S. R. (2015). Using theory of Planned Behavior in Predicting Intention to Invest: Case of Indonesia. International Academic Research Journal of Business and Technology, 1(2), 137-141.

Sugiyono (2017). Metode Penelitian Kuantitatif, Kualitatif, dan RED. Bandung: Alfabeta.

Venkatesh, V., \& Davis, F. D. (1996). A Model of the Antecedents of Perceived Ease of Use: Development and test. Decision Sciences, 27(3), 451-481.

Venkatesh, V., \& Davis, F. D. (2000). A Theoretical Extension of the Technology Acceptance Model: Four Longitudinal field Studies. Management Science, 46(2), 186-204.

Wang, H., Chen, K., Zhu, W., \& Song, Z. (2015). A Process Model on P2P Lending. Financial Innovation, 1(1), 3.

Wang, P., Zheng, H., Chen, D., \& Ding, L. (2015). Exploring the Critical factors Influencing Online Lending Intentions. Financial Innovation, 1(1), 8.

Zhang, T., Tang, M., Lu, Y., \& Dong, D. (2014). Trust Building in Online peer-topeer Lending. Journal of Global Information Technology Management, 17(4), 250266. 
This page is intentionally left blank 